\title{
Molecular genetics of congenital central hypoventila- tion syndrome and Haddad syndrome
}

Jae-Ho Lee ${ }^{1}$ and Dae-Kwang Kim ${ }^{2-4, *}$

Departments of ${ }^{1}$ Anatomy and ${ }^{2}$ Medical Genetics, Keimyung University School of Medicine, Daegu, Korea

${ }^{3}$ Institute for Medical Genetics, Keimyung University School of Medicine, Daegu, Korea

${ }^{4}$ Hanvit Institute for Medical Genetics, City Women's Clinic, Daegu, Korea

\begin{abstract}
Congenital central hypoventilation syndrome (CCHS) is a disorder of the autonomic nervous system characterized by a decreased response to hypercarbia. CCHS is frequently associated with congenital megacolon; the combination is called Haddad syndrome. CCHS is associated with dysfunction in respiratory features of the autonomic nervous system and with other disorders, including facial deformities, cardiovascular symptoms, and tumors. Patients with CCHS frequently have a mutation in the homeobox protein $2 \mathrm{~b}(\mathrm{PHOX} 2 \mathrm{~B})$ gene. Most mutations involve heterozygous expansion of alanine repeats (GCN). Interestingly, a higher polyalanine repeat number is associated with a more severe clinical phenotype. To clarify the role of $P H O X 2 B$ in disease pathogenesis, we introduce and review the clinical and molecular features of CCHS and Haddad syndrome.
\end{abstract}

Key words: Congenital central hypoventilation syndrome, Haddad syndrome, $P H O X 2 B$.

\section{Introduction}

Congenital central hypoventilation syndrome (CCHS), first reported in 1970 by Mellins et al. [1], is characterized by sleepassociated respiratory insufficiency and markedly impaired ventilatory responses to hypercarbia and hypoxemia. The syndrome is also known as Ondine's curse (online mendelian inheritance in man [OMIM] 209880). Similar cases have been reported by many investigators [2-5]. CCHS has been associated with several disorders, including neuroblastoma, ganglioneuroma, and, most frequently, Hirschsprung disease (HSCR) because of broader structural and functional impairments of the autonomic nervous system [6-8]. HSCR (congenital megacolon; OMIM 142623) occurs in 16\% of CCHS patients. The combination is referred to as Haddad syndrome
[6]. Haddad syndrome is extremely rare, with under 100 cases reported in the literature [9].

In 2003, molecular genetic approaches showed that CCHS results from mutation of the homeobox protein $2 \mathrm{~b}(\mathrm{PHOX} 2 \mathrm{~B})$ gene [10]. Many patients with CCHS have a heterozygous mutation consisting of 5 to 9 alanine expansions within a 20-residue polyalanine tract. CCHS genotypes, comprising various mutations in the $P H O X 2 B$ gene, are associated with different degrees and mechanisms of cellular dysfunction, which have implications for the severity of CCHS $[8,11-13]$. The genotypephenotype association has been investigated, and the PHOX2B genotype is now a useful genetic marker for the assessment of CCHS [14]. Children with CCHS now survive into adulthood, and the clinical value of the $P H O X 2 B$ mutation in CCHS continues to be evaluated by following these patients.

Received: 7 April 2014, Accepted: 17 May 2014, Published: 30 June 2014

${ }^{*}$ Corresponding author: Dae-Kwang Kim, M.D., Ph.D.

Department of Medical Genetics, Keimyung University School of Medicine, 2800 Dalgubeol-daero, Dalseo-gu, Daegu 704-701, Korea.

Tel: +82-53-580-3832, Fax: +82-53-580-3835, E-mail: dkkimmd@kmu.ac.kr

Conflict of interest: We declare that we do not have any conflicts of interests.

(ㄷ) This is an open-access article distributed under the terms of the Creative Commons Attribution Non-Commercial License (http://creativecommons.org/licenses/by-nc/3.0/) which permits unrestricted non-commercial use, distribution, and reproduction in any medium, provided the original work is properly cited.

(c) Copyright 2014 by the Korean Society of Medical Genetics 
In Korea, Ahn et al. [15] reported the first case of CCHS in 1993. Several additional cases have been reported to date $[11,16-19]$. With early diagnosis and immediate intervention, the prognosis of CCHS patients has improved in the last decade. However, further research is needed to help Korean patients and their families. To this end, we review the clinical and genetic characteristics of CCHS and Haddad syndrome. We also discuss the clinical and genetic importance of research with a larger number of cases and long-term follow-up in Korea.

\section{Clinical Features}

The first study by Mellins et al. [1] and subsequent reports focused primarily on CCHS as a disorder of ventilatory control in which the automatic control of breathing is absent or impaired.The International Classification of Sleep Disorders proposed diagnostic criteria for CCHS, which include the following: (1) the patient exhibits shallow breathing or cyanosis and apnea in the perinatal period; (2) hypoventilation is worse during sleep than in wakefulness; (3) the ventilatory response to hypoxia and hypercapnia is absent or diminished; (4) polysomnographic monitoring during sleep demonstrates hypercapnia and hypoxia, predominantly without apnea; (5) no primary lung disease or ventilatory muscle dysfunction showing hypoventilation; and (6) no sleep disorder, such as infant sleep apnea. The minimal set of criteria to be met for diagnosis is (1), (2), (5), and (6).

CCHS has been reported in association with several other disorders. Haddad et al. [6] described a combination of CCHS and HSCR, named Haddad syndrome. Patients with Haddad syndrome had reduced esophageal motility and control of heart rate. The incidence of HSCR in CCHS cases varies between 16\% and $50 \%$, and the incidence of CCHS is $1.5 \%$ among HSCR cases [10,20-22]. A CCHS patient with distinctive facial features (antimongoloid slanting eyes, triangular mouth, small nose, and low-set, posteriorly rotated ears) was reported by Minutillo et al. [23]. A study of numerous cases with long-term comprehensive follow-up showed that CCHS patients manifested a spectrum of clinical symptoms that reflect dysfunction of the autonomic nervous system, such as severe constipation, difficulty feeding, decreased perception of discomfort, pupillary abnormalities, decreased perception of anxiety, profuse sweating, and decreased basal body temperature [24]. A high percentage of CCHS patients had cardiovascular symptoms (decreased heart rate variability, vasovagal syncope, cardiac dysrhythmias) and ophthalmologic abnormalities (sluggish or unreactive pupils, abnormal tearing, strabismus, anisocoria, miosis) [24]. Tumors of autonomic neural crest derivatives, such as neuroblastoma, ganglioneuroblastoma, and ganglioneuroma, were also found in approximately 5-10\% of CCHS cases, which represents a 500 -fold increased risk for such tumors in patients with CCHS, when compared with a rate of 1 in 10,000 among the general population $[8,25]$. These tumors typically present before 2 years of age in multiple locations including adrenal glands, chest, spinal cord, or mediastinum.

Cases of late-onset CCHS with pulmonary hypertension or clinically significant, persistent alveolar hypoventilation following an acute respiratory illness have been described [2630]. However, the patients had subclinical or unrecognized diseases when they were children. Therefore, molecular genetic tests should be performed promptly when there is suspicion of late-onset CCHS. The number of reported cases may increase as recognition of the disease grows. A worldwide epidemiological survey estimates there are 500 living patients with CCHS [31].

\section{Molecular Genetics}

The human PHOX2B gene (OMIM 603851) maps to chromosome 4p12 and encodes a highly conserved, 314-aminoacid homeobox transcription factor with polyalanine repeats of 9 and 20 residues. $P H O X 2 B$ regulates the development of the autonomic nervous system and the determination of autonomic neural crest derivatives. Given these roles of $P H O X_{2} B$, Amiel et al. [10] investigated $P H O X 2 B$ as a candidate gene in CCHS. De novo mutations of the $P H O X 2 B$ gene were found in $62 \%$ (18/29) of CCHS patients. The most common PHOX2B mutation in CCHS is a heterozygous expansion of alanine repeats (GCN). In individuals with CCHS, 1 of the 2 alleles contains too many repeats (between 25 and 33), whereas the other allele has 20 repeats (the normal number) (Fig. 1).

Weese-Mayer et al. [32] found alanine expansions in 65 of 67 CCHS patients, and further study identified PHOX2B mutations, not involving alanine expansion, in the 2 remaining CCHS cases. Thus, all patients had a $P H O X 2 B$ mutation, indicating that $P H O X 2 B$ is the disease-defining gene for CCHS. Interestingly, the results suggested an association between repeat length and the severity of the CCHS phenotype. Matera et al. [33] investigated the PHOX2B mutation in $27 \mathrm{CCHS}$ patients, including 3 with associated HSCR and 3 with late-onset CCHS. They also showed that phenotype severity increased with increasing polyalanine 


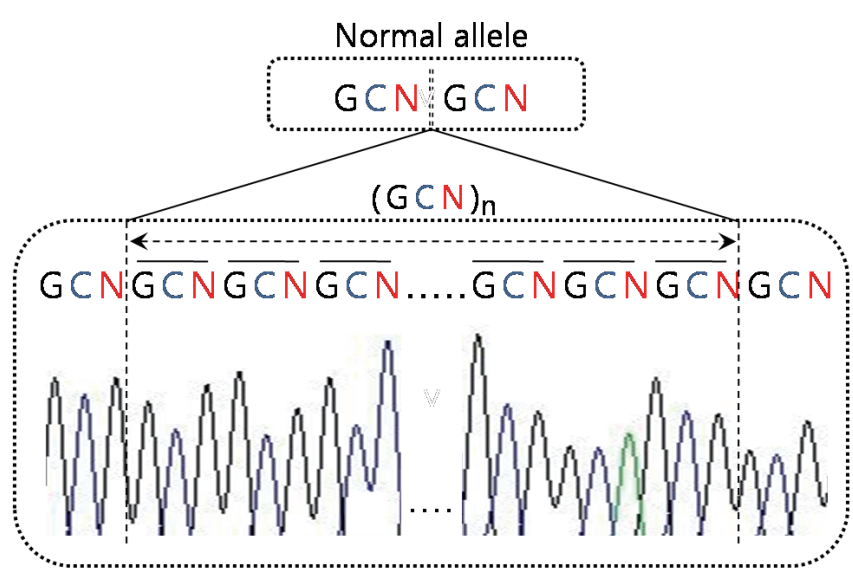

Mutation allele

Fig. 1. Heterozygous mutation of the $P H O X 2 B$ gene in the congenital central hypoventilation syndrome. Mutated alleleshave a greater number of alanine repeats (GCN) than the normal allele.

expansion size. Increased repeat length was associated with severe respiratory symptoms, a long R-R interval in Holter monitoring, and facial phenotypes [34,35]. Results by Trochet et al. [8] strongly supported this genotypephenotype interaction. Short alanine expansions $(+5$ to +7$)$ were found in patients with isolated CCHS, but were rare in patients with Haddad syndrome (CCHS+HSCR). Haddad syndrome patients with tumors tended to have longer alanine expansions (>+8). Interestingly, CCHS patients with malignant tumors of the sympathetic nervous system carried either a missense mutation or a heterozygous frameshift mutation in the $P H O X 2 B$ gene. Review of these results demonstrated that HSCR and neural crest tumors were more frequently associated with missense or frameshift mutations of $P H O X 2 B$ than with the polyalanine expansion. This led to the conclusion that missense or frameshift mutations produce more severe dysfunction in PHOX2B [8,32-35]. However, the relationship was not strict, and further study of additional cases is needed to confirm the hypothesis.

In HSCR, mutations in RET and in the endothelin signaling pathway, including the endothelin B receptor gene (EDNRB) and the endothelin 3 gene (EDN3), have been reported [36-39]. Because CCHS and HSCR share a common molecular pathology, mutations in RET, EDNRB, and EDN3 were investigated in CCHS and Haddad syndrome. Bolk et al. [40] found mutation of EDN3 in CCHS and Haddad syndrome. However, further study identified no EDNRB or EDN3 mutations [41]. Subsequently, mutations in the rearranged during transfection (RET)-glial cellderived neurotrophic factor (GDNF) pathway were reported in $14 \%(1 / 7)$ of CCHS and $14 \%(1 / 7)$ of Haddad syndrome patients by Amiel et al. [41]. Although these mutations were

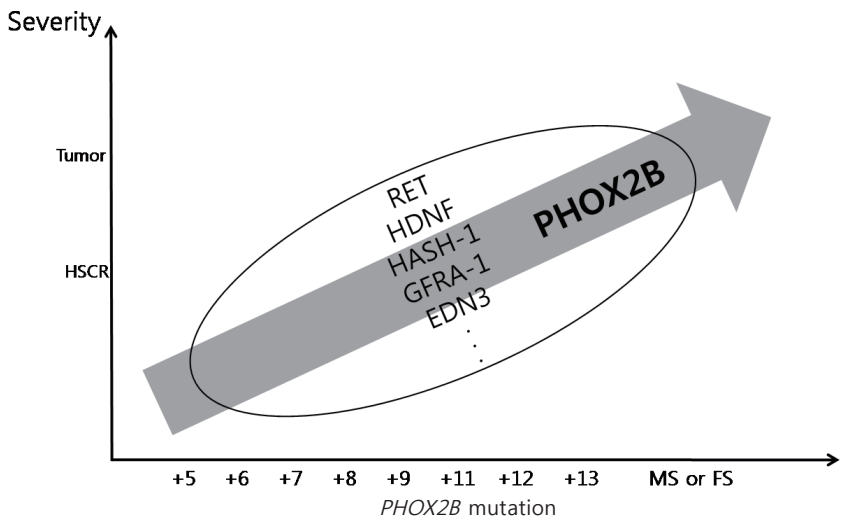

Fig. 2. $P H O X 2 B$ mutation and the congenital central hypoventilation syndrome (CCHS) severity. On the $x$-axis, plus signs $(+)$ indicate the number of supernumerary alanine expansions. Higher expansion number and missense mutations (MS) or frameshift mutations (FS) mutation induce more severe symptoms in Hirschsprung disease (HSCR) patients, including tumors (neuroblastomas). However, the association between these severe symptoms and other genes in the circle is still unknown.

present in a minority of patients, their occurrence suggests that interactive polygenic inheritance (at least 3 genes belonging to distinct signaling pathways) is involved in CCHS.

Mutation of brain-derived neurotrophic factor (BDNF) was studied in $14 \mathrm{CCHS}$ patients and 5 Haddad syndrome patients. BDNF mutation was identified in a CCHS patient whose father did not have CCHS but presented with postural hypotension and vasovagal syncope [32]. As newborns, Mash-1+/-heterozygous mice exhibit impaired ventilator responses to hypercarbia. The human ortholog of Mash-1 (HASH-1) has been investigated as a candidate gene for CCHS [42]. Mutation in $\mathrm{HASH}-1$ was found in 2 patients with CCHS $(10.5 \%, 2 / 19)$ and 1 patient with Haddad syndrome $(9.1 \%, 1 / 11)$ [43].

Sasaki et al. [22] studied RET, GDNF, GFRA 1, PHOX2A, PHOX2B, $H A S H-1, E D N 1, E D N 3, E D N R B$, and BDNF in 7 patients with CCHS and 3 patients with Haddad syndrome. They found no mutations in the EDN3-EDNRB signaling pathway or in the $B D N F$ gene. However, mutations in RET, GFRA 1, PHOX2A, and $H A S H-1$ were found, supporting the possibility of their involvement in the pathogenesis of CCHS. To clarify the pathogenesis of CCHS and Haddad syndrome, further analysis of additional cases and candidate genes is required.

\section{Conclusion}

In a relatively short period of time, molecular genetic studies have defined the clinical characteristics of CCHS for diagnosis 
and treatment. As a result, the prognosis and quality of life of CCHS patients have improved. Patients now survive into adulthood, and their offspring represent a new generation of CCHS patients. Analysis of PHOX2B mutations may predict disease phenotype and prognosis. However, its association with other mutations is still unknown (Fig. 2). In Korea, there are few reports describing CCHS and Haddad syndrome [11,17-19]. Further data on patients with CCHS and Haddad syndrome in Korea should be gathered.

\section{References}

1. Mellins RB, Balfour HH Jr, Turino GM, Winters RW. Failure of automatic control of ventilation (Ondine's curse). Report of an infant born with this syndrome and review of the literature. Medicine (Baltimore) 1970;49:487-504

2. Deonna T, Arczynska W, Torrado A. Congenital failure of automatic ventilation (Ondine's curse). A case report. J Pediatr 1974;84:710-4.

3. O'Dell K, Staren E, Bassuk A. Total colonic aganglionosis (Zuelzer-Wilson syndrome) and congenital failure of automatic control of ventilation (Ondine's curse). J Pediatr Surg 1987;22:1019-20.

4. Oren J, Kelly DH, Shannon DC. Long-term follow-up of children with congenital central hypoventilation syndrome. Pediatrics 1987;80:37580.

5. Yasuma F, Nomura H, Sotobata I, Ishihara H, Saito H, Yasuura K, et al. Congenital central alveolar hypoventilation (Ondine's curse): a case report and review of the literature. Eur J Pediatr 1987;146:81-3.

6. Haddad GG, Mazza NM, Defendini R, Blanc WA, Driscoll JM, Epstein $M A$, et al. Congenital failure of automatic control of ventilation, gastrointestinal motility and heart rate. Medicine (Baltimore) 1978;57:517-26.

7. Swaminathan S, Gilsanz V, Atkinson J, Keens TG. Congenital central hypoventilation syndrome associated with multiple ganglioneuromas. Chest 1989;96:423-4.

8. Trochet D, O'Brien LM, Gozal D, Trang H, Nordenskjöld A, Laudier B, et al. $\mathrm{PHOX} 2 \mathrm{~B}$ genotype allows for prediction of tumor risk in congenital central hypoventilation syndrome. Am J Hum Genet 2005;76:421-6.

9. Tomycz ND, Haynes RL, Schmidt EF, Ackerson K, Kinney HC. Novel neuropathologic findings in the Haddad syndrome. Acta Neuropathol 2010;119:261-9.

10. Amiel J, Laudier B, Attié-Bitach T, Trang H, de Pontual L, Gener B, et al. Polyalanine expansion and frameshift mutations of the pairedlike homeobox gene $\mathrm{PHOX} 2 \mathrm{~B}$ in congenital central hypoventilation syndrome. Nat Genet 2003;33:459-61.

11. Kwon MJ, Lee GH, Lee MK, Kim JY, Yoo HS, Ki CS, et al. PHOX2B mutations in patients with Ondine-Hirschsprung disease and a review of the literature. Eur J Pediatr 2011;170:1267-71.
12. Jennings $\sqcup, Y u$ M, Rand CM, Kravis N, Berry-Kravis EM, Patwari PP, et al. Variable human phenotype associated with novel deletions of the PHOX2B gene. Pediatr Pulmonol 2012;47:153-61.

13. Bachetti T, Di Duca M, Della Monica M, Grappone L, Scarano G, Ceccherini I. Recurrence of CCHS associated PHOX2B poly-alanine expansion mutation due to maternal mosaicism. Pediatr Pulmonol 2014;49:E45-7.

14. Rand CM, Patwari PP, Carroll MS, Weese-Mayer DE. Congenital central hypoventilation syndrome and sudden infant death syndrome: disorders of autonomic regulation. Semin Pediatr Neurol 2013;20:4455.

15. Ahn YM, Choi HR, Lee HJ, Dong ES, Hong SJ, Moon HN, et al. A case of congenital central hypoventilation syndrome(ondine's curse) with hirschsprung's disease. Pediatr Allergy Respir Dis 1993;3:113-20.

16. Choi JH, Oh JH, Kim JH, Koh DK, Hong SC. Congenital central hypoventilation syndrome combined with Hirschsprung disease diagnosed in the neonatal period. Korean J Pediatr 2006;49:446-50.

17. Kwon KA, Park SE, Byun SY, Kim SY, Hwang SH. A case of congenital central hypoventilation syndrome with $\mathrm{PHOX} 2 \mathrm{~B}$ gene mutation in a Korean neonate. J Korean Med Sci 2010;25:1237-40.

18. Lee CW, Lee JH, Jung EY, Choi SO, Kim CS, Lee SL, et al. Haddad syndrome with $\mathrm{PHOX} 2 \mathrm{~B}$ gene mutation in a Korean infant. J Korean Med Sci 2011;26:312-5.

19. Chung WD, Lim GY, Kim SY, Chung JH, Kim SJ. Haddad syndrome presenting with abdominal distension associated with long-segment aganglionosis. Clin Imaging 2012;36:149-52.

20. Weese-Mayer DE, Silvestri JM, Menzies $\sqcup_{1}$ Morrow-Kenny AS, Hunt CE, Hauptman SA. Congenital central hypoventilation syndrome: diagnosis, management, and long-term outcome in thirty-two children. J Pediatr 1992;120:381-7.

21. Croaker GD, Shi E, Simpson E, Cartmill T, Cass DT. Congenital central hypoventilation syndrome and Hirschsprung's disease. Arch Dis Child 1998;78:316-22.

22. Sasaki A, Kanai M, Kijima $K$, Akaba $K$, Hashimoto $M$, Hasegawa $H$, et al. Molecular analysis of congenital central hypoventilation syndrome. Hum Genet 2003;114:22-6.

23. Minutillo C, Pemberton PJ, Goldblatt J. Hirschsprung's disease and Ondine's curse: further evidence for a distinct syndrome. Clin Genet 1989:36:200-3.

24. Weese-Mayer DE, Shannon DC, Keens TG, Silvestri JM; American Thoracic Society. Idiopathic congenital central hypoventilation syndrome: diagnosis and management. American Thoracic Society. Am J Respir Crit Care Med 1999;160:368-73.

25. Rohrer T, Trachsel D, Engelcke G, Hammer J. Congenital central hypoventilation syndrome associated with Hirschsprung's disease and neuroblastoma: case of multiple neurocristopathies. Pediatr Pulmonol 2002:33:71-6.

26. Katz ES, McGrath S, Marcus CL. Late-onset central hypoventilation with hypothalamic dysfunction: a distinct clinical syndrome. Pediatr 
Pulmonol 2000;29:62-8.

27. Trang H, Laudier B, Trochet D, Munnich A, Lyonnet S, Gaultier $C_{\text {, }}$ et al. PHOX2B gene mutation in a patient with late-onset central hypoventilation. Pediatr Pulmonol 2004;38:349-51.

28. Weese-Mayer DE, Berry-Kravis EM, Zhou L. Adult identified with congenital central hypoventilation syndrome--mutation in PHOX2b gene and late-onset CHS. Am J Respir Crit Care Med 2005;171:88.

29. Doherty LS, Kiely JL, Deegan PC, Nolan G, McCabe S, Green AJ, et al. Lateonset central hypoventilation syndrome: a family genetic study. Eur Respir J 2007;29:312-6.

30. Onal H, Ersen A. A case of late-onset central hypoventilation syndrome with hypothalamic dysfunction: through a new phenotype. Turk J Pediatr 2010;52:198-202.

31. Vanderlaan $M$, Holbrook CR, Wang M, Tuell A, Gozal D. Epidemiologic survey of 196 patients with congenital central hypoventilation syndrome. Pediatr Pulmonol 2004;37:217-29.

32. Weese-Mayer DE, Bolk S, Silvestri JM, Chakravarti A. Idiopathic congenital central hypoventilation syndrome: evaluation of brainderived neurotrophic factor genomic DNA sequence variation. Am J Med Genet 2002;107:306-10.

33. Matera I, Bachetti T, Puppo F, Di Duca M, Morandi F, Casiraghi GM, et al. PHOX2B mutations and polyalanine expansions correlate with the severity of the respiratory phenotype and associated symptoms in both congenital and late onset Central Hypoventilation syndrome. J Med Genet 2004;41:373-80.

34. Todd ES, Weinberg SM, Berry-Kravis EM, Silvestri JM, Kenny AS, Rand $\mathrm{CM}$, et al. Facial phenotype in children and young adults with PHOX2Bdetermined congenital central hypoventilation syndrome: quantitative pattern of dysmorphology. Pediatr Res 2006;59:39-45.
35. Gronli JO, Santucci BA, Leurgans SE, Berry-Kravis EM, Weese-Mayer DE. Congenital central hypoventilation syndrome: $\mathrm{PHOX} 2 \mathrm{~B}$ genotype determines risk for sudden death. Pediatr Pulmonol 2008;43:77-86.

36. Attié T, Pelet A, Edery P, Eng C, Mulligan LM, Amiel J, et al. Diversity of RET proto-oncogene mutations in familial and sporadic Hirschsprung disease. Hum Mol Genet 1995;4:1381-6.

37. Attié $T$, Till M, Pelet A, Amiel J, Edery P, Boutrand $L$, et al. Mutation of the endothelin-receptor B gene in Waardenburg-Hirschsprung disease. Hum Mol Genet 1995;4:2407-9.

38. Edery P, Attié T, Amiel J, Pelet A, Eng C, Hofstra RM, et al. Mutation of the endothelin-3 gene in the Waardenburg-Hirschsprung disease (ShahWaardenburg syndrome). Nat Genet 1996;12:442-4.

39. Puffenberger EG, Hosoda K, Washington SS, Nakao K, deWit D, Yanagisawa $\mathrm{M}$, et al. A missense mutation of the endothelin-B receptor gene in multigenic Hirschsprung's disease. Cell 1994;79:1257-66.

40. Bolk S, Angrist M, Xie J, Yanagisawa M, Silvestri JM, Weese-Mayer $D E$, et al. Endothelin-3 frameshift mutation in congenital central hypoventilation syndrome. Nat Genet 1996;13:395-6.

41. Amiel J, Salomon R, Attié T, Pelet A, Trang H, Mokhtari M, et al. Mutations of the RET-GDNF signaling pathway in Ondine's curse. Am J Hum Genet 1998:62:715-7.

42. Dauger S, Renolleau S, Vardon G, Népote V, Mas C, Simonneau M, et al. Ventilatory responses to hypercapnia and hypoxia in Mash-1 heterozygous newborn and adult mice. Pediatr Res 1999;46:535-42.

43. de Pontual L, Népote V, Attié-Bitach T, Al Halabiah H, Trang H, Elghouzzi $V$, et al. Noradrenergic neuronal development is impaired by mutation of the proneural HASH-1 gene in congenital central hypoventilation syndrome (Ondine's curse). Hum Mol Genet 2003;12:3173-80. 